\title{
PREPARATION OF MICROBIOLOGICAL AGENTS FOR ORGANIC POLLUTANTS REMOVAL IN WASTEWATER
}

\author{
Angela Cincilei*1, Svetlana Tolocichina ${ }^{1}$, Inna Rastimesina ${ }^{1}$, Ion Dragalin ${ }^{2}$, \\ Veronica Dumbraveanu ${ }^{2}$, Nina Streapan ${ }^{1}$, Vera Mamaliga ${ }^{1}$ \\ ${ }^{1}$ Institute of Microbiology and Biotechnology, Academy of Sciences of Moldova, MD-2028 Chisinau, R.Moldova \\ ${ }^{2}$ Institute of Chemistry, Academy of Sciences of Moldova, MD-2028 Chisinau, R.Moldova \\ E-mail: angela_cincilei@yahoo.fr
}

\begin{abstract}
The present article is dedicated to biochemical aspects of degradation processes of persistent organic pollutant benzothiazole by immobilized Rhodococcus rhodochrous cells, such as entrapped in Ca-alginate beads, as being immobilized on some solid carries. The mineralization of toxicant was complete and biodestructive capacity of entrapped in alginate rhodococci increased with each new experimental cycle.
\end{abstract}

Keywords: Benzothiazoles, biodegradation, immobilized cells, Rhodococcus sp.

\section{Introduction}

Biotechnological processes based on immobilized viable cells have developed rapidly over the last 30 years. The use of immobilized microbial cells (IC) to carry out biotransformation or biosynthesis, and to improve fermentation processes, has been one of the most interesting techniques and has been extensively investigated [1,2]. A large part of published data on IC systems concerns their operation in bioreactors where they perform biosyntheses or bioconversions leading to a variety of compounds. IC cultures have also been widely applied to the treatment of domestic or industrial wastewaters containing different types of pollutants such as nitrate/nitrite ions, heavy metals or organic compounds recalcitrant to biodegradation due high resistance of IC to environmental stresses, in particular, the exposure to toxic compounds.

As physiological point of view, IC systems can be separated into wholly artificial and naturally occurring ones. In the first category, microbial cells are artificially entrapped in or attached to various matrices/supports where they keep or not a viable state, depending on the degree of harmfulness of the immobilization procedure. Polysaccharide gel matrices, more particularly Ca-alginate hydrogels, are by far the most frequently used materials for harmless cell entrapment [3].

In comparison with free suspended cells, immobilized cells exhibit tolerance to toxic substances [4], enhance fermentation productivity [5], can adapt to a wide range of $\mathrm{pH}$ environments [6] and high process temperature [7,8] and are re-usable $[9,10]$ (Tab.1). Published results show contradictory effects of immobilization on growth rate, i.e. decreased, unchanged or enhanced growth rates of IC compared to free cultures [11-13]. Mass transfer limitation in IC systems gives the most evident explanation to reduced IC growth rate. On the other hand, the growth-promoting action of immobilization has been attributed to protective effects of the support, e.g. against high-shear environment [14] or acidification $[6,15]$.

Potential advantages of viable IC systems over conventional fermentations

Table 1 (adapted by Junter a.Jouenne, 2004 from Mattiasson, 1983)

\begin{tabular}{|ll|}
\hline (a) & Higher reaction rates due to increased cell densities \\
\hline (b) & Possibilities for regenerating the biocatalytic activity of IC structures \\
\hline (c) & Ability to conduct continuous operations at high dilution rate without washout \\
\hline (d) & Easier control of the fermentation process \\
\hline (e) & Long-term stabilization of cell activity \\
\hline (f) & Reusability of the biocatalyst \\
\hline (g) & Higher specific product yields \\
\hline
\end{tabular}

The biodegradation of toxic compounds also represents a preferential application field of IC systems. The high biodegradation efficiency and operational stability of IC cultures, highlighted for instance, during continuous biodegradation assays of phenol and phenolic derivatives, is typically ascribed to some protecting effect of the immobilization support [16], rather than to enhanced specific degradation capacity that might involve physiological modification in IC. IC is also characterized by a high resistance to antimicrobial agents such as biocides and antibiotics. This resistance has been observed for artificially immobilized microbial cultures, e.g. alginate entrapped bacteria exposed to sanitizers [17] or antibiotics [18], but more frequently for natural IC systems, namely biofilms, which are implied in a variety of industrial, environmental and medical situations. 
Benzothiazole (BT) and its derivatives (BTs) belong to an extensive family of synthetic compounds. BTs are used in various fields e.g. in the tire industry as catalysts in vulcanization processes, as medicines, as pesticides/ biocides and in the manufacture of azo-dyes [19]. As a consequence of their large range of applications, these compounds are often found in the aquatic environment [20]. Some of these compounds are attributed to persistent organic compounds with carcinogenic properties [21]. Therefore, it is important to investigate the processes of pollutant detoxication with the help of active micro organisms capable of bringing about a complete degradation of the target compound.

\section{Results and Discusion}

Cells immobilization on alginate: Generally, the biodegradation of benzothiazole by active cells of bacteria R.rhodochrous OBT 18 in suspension is complete in the first 3 hours from the start of the experiment. The process is accompanied by the appearance of two metabolites - 2-hydroxybenzothiazole (OBT), and dihydroxybenzothiazole (diOBT), which transformations to the complete disappearance occur quickly. Thus, the complete mineralization of BT (including metabolites) lasts 10 hours [22].

We know about successful examples of degradation of organic pollutants with the active bacteria, immobilized in alginate of 2.0\% [23], 2.5\% [24], 2.6\% [25], 2.7\% [26]. Therefore, we tried to find the minimal useful concentration of alginate career in order to avoid the mass transfer limitation in IC system. For this purpose, the repeated ( 3 cycles) degradation of BT by rhodococci immobilized in five different concentrations of alginate (1.5 $\ldots .3 .5 \% \mathrm{w} / \mathrm{v}$ ) was compared. The beads forms, shapes, their stability were analyzed visually for 3 cycles 24 hours each and more (till 7 days of incubation). Neither changing of the beads shape, no opalescence of BT solution was noted for variants $2.0-3.5 \%$ alginate. For the next experiments the optimal concentration of alginate $-2.0 \%$ has been chosen, to assure a good diffusion of xenobiotic, metabolites, and oxygen in alginate / water system.

BT, with a concentration from $300 \mathrm{mg} \mathrm{L}^{-1}$, or $2.2 \mathrm{mMol}$, is toxic for R.rhodochrous bacteria. Or, one of recognized advantages of immobilization of active microorganisms on solid supports is the protection of microbial cells against the toxic action of organic compounds and its metabolites subdued to the transformation. In the variant of BT $1.0 \mathrm{mMol}$ degradation, the experimental analyze of data obtained by the HPLC method showed the high destructive efficiency of the alginate immobilized bacteria during the 3 consecutive cycles. More than that, the destructive capacity of immobilized bacteria increases by every cycle (Tab.2).

Degradation of $1.0 \mathrm{mMol}$ BT by immobilized in Ca-alginate $2 \%$ rhodococci, the 3 cycles of degradation

Table 2

\begin{tabular}{|c|c|c|c|c|c|c|c|c|}
\hline \multirow{2}{*}{$\begin{array}{c}\text { Incubation, } \\
\text { hours }\end{array}$} & \multicolumn{4}{|c|}{ BT $1.0 \mathrm{mMol}+2 \%$ (alginate with cells) } & \multicolumn{4}{|c|}{ BT 1.0 mMol + free cells } \\
\hline & $\begin{array}{l}\text { BT, } \\
\text { mMol }\end{array}$ & $\begin{array}{l}\text { OBT, } \\
\text { mMol }\end{array}$ & $\begin{array}{c}\text { diOBT, } \\
\text { area }\end{array}$ & \% degr. & $\begin{array}{c}\text { BT, } \\
\text { mMol }\end{array}$ & $\begin{array}{l}\text { OBT, } \\
\text { mMol }\end{array}$ & $\begin{array}{c}\text { diOBT, } \\
\text { area }\end{array}$ & \% degr. \\
\hline \multicolumn{9}{|c|}{$\mathrm{I}^{\text {st }}$ cycle of degradation } \\
\hline 0 & 0,94 & - & - & 6,0 & 0,99 & 0,008 & - & 1,0 \\
\hline 3 & 0,48 & 0,17 & 2,6 & 52,0 & 0,26 & 0,37 & 3,8 & 74,0 \\
\hline 5 & 0,22 & 0,28 & 4,4 & 78,0 & 0,03 & 0,41 & 8,5 & 97,0 \\
\hline 24 & - & 0,01 & - & 100,0 & - & - & - & 100,0 \\
\hline \multicolumn{9}{|c|}{$2^{\text {nd }}$ cycle of degradation } \\
\hline 5 & - & 0,19 & 5,5 & 100,0 & & & & \\
\hline 24 & - & 0,01 & - & 100,0 & & & & \\
\hline \multicolumn{9}{|c|}{$3^{\text {rd }}$ cycle of degradation } \\
\hline 5 & - & 0,11 & 5,8 & 100,0 & & & & \\
\hline 24 & - & 0,01 & - & 100,0 & & & & \\
\hline
\end{tabular}

Thus, after 5 hours of the $1^{\text {st }}$ cycle in the water were found $22 \%$ of residual BT that was missing in the 2nd and 3rd cycles, after 5 hours. This phenomena shows the good estate of immobilized in alginate bacteria. The chosen organic support allowed the multiplication, inside of it, of the active bacteria, so that the rate of biodestruction increases with each new cycle of treatment.

The decrease of destructive capacity of immobilized in alginate bacteria when high concentrations of BT can be attributed to the decreasing of the number of bacteria cells inside of the alginate through the duration of a degradation cycle. For verifying this hypothesis, there was measured the number of viable cells (colony-forming units, $\mathrm{CFU}$ ) inside the alginate beads before and after first cycle of degradation, in two extreme concentration of BT -1.0 and $5.0 \mathrm{mMol}$. The obtained data showed the strong reduction of the number of bacteria in the alginate - to 0,64 x $10^{7}$ CFU per alginate bead - in the variant $5.0 \mathrm{mMol}$ BT after 24h of the first cycle of degradation. In opposition to this, as it was confirmed by the HPLC analyzes, the alginate assured the good state and the destructive efficiency of R.rhodochrous bacteria, for the concentration of BT $1 \mathrm{mMol}$ : the number of rhodocci increased with approx.206\% 
(or by 3.1 times) and was 3,3 x $10^{7} \mathrm{CFU}$ per bead (after $24 \mathrm{~h}$ of the $\mathrm{I}^{\text {st }}$ cycle of degradation) compared to $1,08 \times 10^{7}$ CFU per initial bead.

Thus, the chromatographic researches of biodestructive efficiency of alginate immobilized active microorganisms were completed and confirmed by microbiological complementary studies of the interested bacteria.

Mainly, by applying two essentially different methods, we showed the preservation of good physiological state of the cells, immobilized in $2 \%$ alginate. In case of concentration of approx $135 \mathrm{mg} / \mathrm{L} \mathrm{BT} \mathrm{(1} \mathrm{mMol),} \mathrm{the} \mathrm{chosen}$ organic support respects the natural metabolic activity and the multiplication of bacteria, so that the rate of biodestruction of toxicants and the number of rhodococci increase with each new cycle of biotransformation. This phenomena comes to confirm the special capacities of calcium alginate hidrogels, that are frequently used as support for a light, tolerant, non-agressive immobilization („,harmless cell entrapment”) of the living cells, in our case - of the microorganisms, and that respect the natural phisiological state of the immobilized cells [27].

Cells adsorption on solid support: One of the major objectives of our researches was to provide a simple, low-cost and efficient carrier and to find immobilization techniques for preparing immobilized microbial cells with the goal of application in waste water treatment. Readily available, low-cost carrier, namely sawdust, alluvial quartz sand, activated carbon (from walnut shell, and from grapes seeds), and diatomite-containing material were tested as supports for adsorptive immobilization of R.rhodochrous cells. Physico-chemical modification (hydrophobization) of sawdust was performed, in order to increase the adhesion of bacteria. Results of laboratory trials showed that solid supports (sand, diatomite, and activated carbon) demonstrated significant level (11,2-7,0 $\mathrm{mg}_{\text {dry cells }}{ }^{-1}$ ) of bacterial immobilization. However, even with the saturation before experiment, the carbon support produces a strong absorbtion of toxicant and doesn't permit to observe the real BT biodegradation process.

In the case of immobilized in the tested solid support bacteria, unlike those immobilized in alginate, complete biodestruction of the toxicant didn't occured. Nevertheless, the results show the superiority of diatomite-immbolized bacteria, that assures 53,2\% (I cycle) and 35,5\% (II cycle) of BT degradation after 24h of incubation. Also we noticed a clear apparition of OBT in a incubation medium during two cycles.

Although the sand assures a good immobilization of 52,8\% from initial quantity of bacteria, the efficiency of BT biodestruction with immobilized in sand rhodococci is low $-19.3 \%$, from which $4.7 \%$ can be atributed to abiotic phenomena.

Our experiments of cells entrapment and adhesion on the support materials were confirmed by scanning electron microscopy investigations (Fig.).
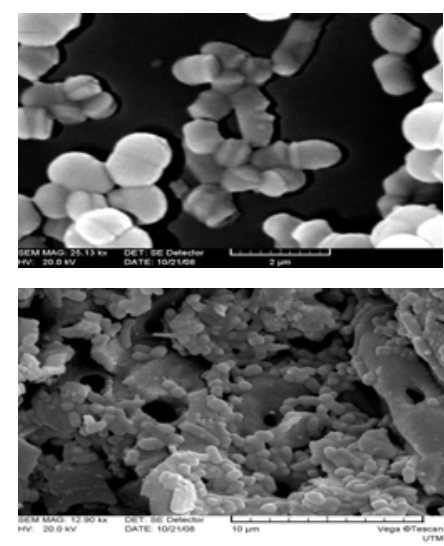
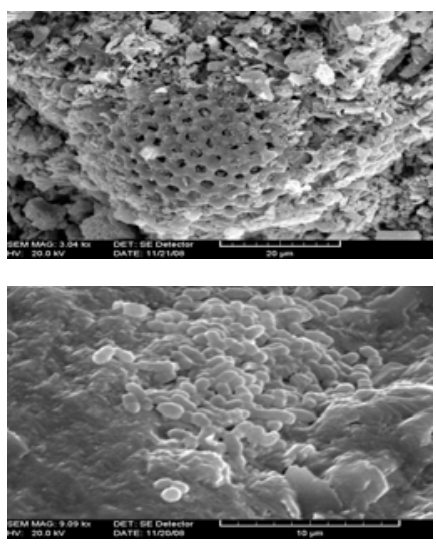
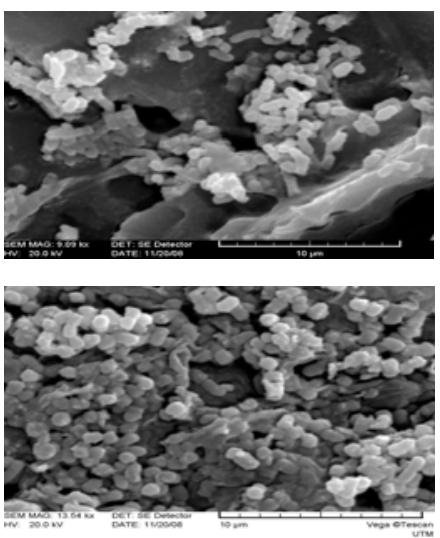

Fig.: (left to right): free and immobilized bacterial cell of R.rhodochrous on the support materials: diatomite-containing material, activated carbon from walnut shell, sawdust, quartz sand, and within alginate beads.

The sand, diatomite-containing material and activated carbon as support materials have been shown to assure a good absorbance of bacteria (52.8, 38.7, and 32.8\%, respectively), and were selected as carriers in the new combined photo-catalytical bio-reactor [28].

\section{Conclusions}

In conclusion, immobilized in alginate active R.rhodochrous OBT 18 bacteria assures the complete mineralisation of pollutant in pure water in the first $5 \mathrm{~h}$ of experiment, and these biodestructive capacity increases with each new cycle. More than that, the alginate support offers the necesary conditions for the natural metabolic activity and multiplication of active bacteria within it. The optimal conditions, that assures the complete elimination of BT by the strain R.rhodochrous OBT18 through several repeated cycles are: concentration of bacteria in alginate $-2.5 \%$, of alginate $-2.0 \%$, of $\mathrm{BT}-$ up to $135 \mathrm{mg} / \mathrm{L}$. 
The prezented researches contributed to the elaboration of the efficient microbiological method of distruction of organic compounds, using the microorganisms immobilized on solid support, and will be implemented in modern regional biotechnologies of environmental decontamination. The diatomite and alginate were recommended as carriers in the new hybrid solid support of immobilizing.

\section{Experimental}

The object of study was water solution of benzothiazole, purchased from Aldrich Ltd (Gillingham, Kent, UK).

BT transformations by rhodococci were studied in "resting cells" experiments with free and immobilized cells by HPLC method. Bacterial strain R.rhodochrous OBT18 from LSEESIB (Blaise Pascal University, France) were used. Cell immobilization was performed by entrapping in calcium alginate matrices (2.0\% w/v) [27], or by absorption in solid supports $(2,1 \% \mathrm{w} / \mathrm{w})$ [29]. The percentage of immobilized biomass was estimated by two different methods: 1) indirectly through turbidity measurement as absorbance at $540 \mathrm{~nm}$ before and after immobilization procedure, 2) directly, by counting the CFU in serially diluting samples of aliquots planted onto nutrient agar. The resting or immobilized cells were incubated with $1.0 \mathrm{mMol} \mathrm{BT}$ in $300-\mathrm{mL}$ Erlenmeyer flaks at $28^{\circ} \mathrm{C}$ under agitation (200 rpm) [22]. The negative controls lacking BT, supports or cells were incubated under the same conditions.

HPLC analyses were performed in isocratic conditions using an Agilent 1200 chromatograph fitted with a precolumn and reversed-phase column Zorbax Eclipse XDB $5 \mu \mathrm{m}\left(\mathrm{C}_{8} 150 \mathrm{x} 4.6 \mathrm{~mm}\right)$ at room temperature. The mobile phase was acetonitrile-water (25/75, v/v), with a flow rate of $1 \mathrm{~mL} / \mathrm{min}$, vol.inj. $-5 \mathrm{mcL}$; $\lambda=265 \mathrm{~nm}$.

Scanning electron microscopy investigations were performed by VEGA TS-5130 microscop.

\section{Acknowledgements}

This cycle of researches was supported by Institutional project 06.411.016 A, and INTAS Ref.Nr.05-104-7596.

\section{References}

[1]. Wijffels, R.H., Ed. Immobilized cells. Springer Verlag: Heidelberg, 2001.

[2]. Junter, G.A.; Jouenne, T. Biotechnol.Advances. 2004, 22, 633-658.

[3]. Gerbsch, N.; Buchholz, R. FEMS Microbiol Rev. 1995, 16, 259-269.

[4]. Lee, S.L.; Cheng, H.Y.; Chen, W.C.; Chou, C.C. Process Biochem. 1998, 33, 453-459.

[5]. Kim, D.J.; Chang, H.N. Biotechnol.Bioeng. 1990, 36, 460-466.

[6]. Buzas, Z.S.; Dallmann, K.; Szajani, B. Biotechnol.Bioeng. 1998, 34, 882-884.

[7]. Bajpai, P.; Margaritis, A. Biotechnol.Bioeng. 1987, 30, 306-313.

[8]. Tan, Q.; Day, D.F. Appl.Microbiol.Biotechnol. 1998, 42, 22-27.

[9]. Paik, H.D.; Glatz, B.A. Appl.Microbiol.Biotechnol. 1994, 42, 22-28.

[10]. Lee, S.L.; Cheng, H.Y.; Chen, W.C.; Chou, C.C. Process Biochem. 1999, 34, 845-850.

[11]. Galazzo, J.L.; Bailey, J.E. Biotechnol.Bioeng. 1990, 36, 417-426.

[12]. Muyima, N.O; Cloete, T.E. Water Res. 1995, 29, 2461-2466.

[13]. Pashova, S.; Slokoska, L.; Sheremetska, P.; Krumova, E. et al. Proc.Biochem. 1999, 35, 15-19.

[14]. Chun, G.-T.; Agathos, S.N. Biotechnol.Bioeng. 1991, 37, 256-265.

[15]. Taipa, M.A.; Cabral, J.M.; Santos, H. Biotechnol.Bioeng. 1993, 41, 647-653.

[16]. Dervakos, G.A.; Webb, C. Biotech.Adv. 1991, 9, 559-612.

[17]. Trauth, E.; Lemaitre, J.-P. Rojas, C.; Divies, C.; Cachon R. Lebensm-Wiss Technol. 2001, 34, $239-243$.

[18]. Coquet, L.; Junter, G.-A. ; Jouenne, T. J.Antimicrob.Chemother. 1998, 42, 755-760.

[19]. Bunescu, A.; Besse-Hoggan, P; Sancelme, M.; Cincilei, A. et al. In: Wang B., Ed. Environmental Biodegradation Research Focus. Nova Publishers: New York, 2008; 159-187.

[20]. De Wever, H.; Weiss, S.; Reemtsma, T.; Vereecken, J. et al. Wat. Res. 2007, 41, 935-945.

[21]. Gaja, M.A.; Knapp, J.S. J.of Appl.Microbiol., 1997, 83, 327-334.

[22]. Besse, P.; Combourieu, B.; Boyse, G.; Sancelme, M.; De Wever, H.; Delort, A.M. Appl. Environ. Microbiol. 2001, 67, 1412-1417.

[23]. Paje, M.L.; Marks, P.; Couperwhite, I. World J. of Microbiol. and Biotechnol. 1998, 14, 675-680.

[24]. Velankar, H.R.; Heble, M.R. Electronic J.of Biotechnol. 2003, 6 (2), 90-103.

[25]. Chang, Y.; Chou, C. Biotechnol.Appl.Biochem. 2002, 35, 69-74.

[26]. Mordocco, A.; Kuek, C.; Jenkins, R. Enzyme Microb. Technol. 1999, 25, 530-536.

[27]. Chorao, C.; Charmantray, F; Besse-Hoggan, P.; Sancelme, M.; Cincilei, A. et al. Chemosphere. 2009, 75, 121128.

[28]. Covaliova, O.; Covaliov, V.; Delort, A.-M.; Mailhot, G.; Cincilei, A. Patent MD 3911 F1 2009.

[29]. Kitova, A.E.; Kuvichkina, T.N.; Ilyasov, P.V. et al. Appl.Biochem and Microbiology (Russian), 2002, 38, 585590. 